\title{
Decentralization and the Composition of Public Expenditure in Spain
}

\author{
Juan González Alegre* \\ European University Institute, Department of Economics.
}

November 15, 2006

\begin{abstract}
This paper examines the effects that fiscal decentralization may have on the economic distribution of public expenditures. The estimation run is based on a model in which the utility of the representative agent from the current public expenditure depends on the distance to the level of the administration that provides it. That would be the cause why decentralized economies could experience a higher the share of current expenditure in the budget of the public administrations, in contrast to public capital. Using data from the seventeen spanish regions (1984-2003) we test the hypothesis and we show that fiscal decentralization is a crutial determinant of the share of the public budget devoted to capital.

Keywords: Fiscal Decentralization, Public Expenditure, Public Capital

JEL Classification Numbers: E62, H54, R58, C23.
\end{abstract}

\section{Introduction.}

The economic justification for whether the allocation of a part of public resources should depend on a decentralized system has to be built on assumptions that create inefficiencies for the centralized counterpart. It turns out to be difficult to find such inefficiencies in a world in which there is a perfect access to information to all agents. Economic theory has traditionally focused on differences of perception about utility, benefit and costs between local and central governments about certain projects, suggested by Oates (1972). He makes a distinction between 'local' and 'global' public goods.

Simultaneously to the development of more sophisticated models that capture the role of decentralization on economic growth -some of them linking also

*Juan.Gonzalez.Alegre@eui.eu 
centralization to the level of public expenditure ${ }^{1}$-, other studies revealed the importance of the composition of public expenditure to achieve optimal rates of growth $^{2}$. However the problem has been rarely focused as an indirect relation from decentralization policy to the composition public expenditure, and from the latter to economic growth. There are some examples described on section 2 , but in this paper we propose an alternative view to the problem since our departure point is a world in which population is only distance-sensitive to public current expenditure, while the utility perceived from public capital would remain independent from the level of the government that provides it.

The response to the theory has been the realization of many empirical studies that have tried to suggest the existence of a relationship between decentralization and growth as a direct or indirect relation ${ }^{3}$. The results are not very conclusive. The link between the level of fiscal decentralization and economic growth and with the level of public expenditure does not reveal a clear causal relationship from the first to the others, although developed countries tend to have higher levels of public spending as well as more decentralized institutions.

The contribution by Arze, Martínez-Vazquez, and McNab (2005) suggests that decentralizing public expenditure may vary its composition. They argue that regional governments spend more in 'public consumption', diminishing the share of the public expenses allocated to investment. They use consolidated data for a panel of 45 countries.

After the acceptance of the Constitution of 1978, Spain has experienced a gradual process of fiscal decentralization. Public spending has increased, from less that 30\% of the GDP in 1976 to more that 50\% nowadays. The central government has passed from controlling almost $80 \%$ of this public spending before the democratization of Spain to control approximately one half of the public budget. Molero (2001) describes how the mayor part of this decentralization policy has affected the regional level of the government instead of the local one.

Using the data from the Spanish regions, we test the hypothesis that the economic distribution of public spending is sensitive to the level of decentralization. In particular, we look at the distribution between public current expenditure and public capital. We show that there exists a clear relationship between them. We interpret this behaviour as a result of the sensitiveness of the demand of public goods by the population to the distance of the jurisdiction that provides them.

The hypothesis leaves opened another question: whether this reallocation of public funds would converge to a more efficient economy or not. In principal a

\footnotetext{
${ }^{1}$ Panizza (1999), Sanz and Velazquez (2002).

${ }^{2}$ Barro (1990), Devarajan, Swaroop and Zou (1996), among others.

${ }^{3}$ Oates (1993), through better development of the markets (Weingast (1995)) or through macroeconomic stability (Martínez-Vazquez and McNab (2005).
} 
certain level of fiscal decentralization would be desirable, but the long-run relationship of public capital with economic growth has been largerly documented, and disminishing public capital expenditure could induce negative externalities ignored by the decision maker.

\section{Literature review. Empirical studies}

The direct relationship between fiscal decentralization and growth has received a significant amount of attention in the empirical literature in the recent years. There are some studies on individual countries, Xie, Davoodi and Zou (1999) conclude for the US an insignificant effect of fiscal decentralization on economic growth. For China, Zhang and Zou (1998) find that the fiscal decentralization policies taken on the 1980s did not promote economic growth. They use a panel data growth model with local level data from 1980 to 1992 for 28 provinces.

The cross-country studies do not seem to find common answer to the question. Davoodi and Zou (1998) find a negative effect of fiscal decentralization on economic growth for developing countries and no clear relationship for the developed countries, while Woller and Phillips (1998) find no relationship for developing countries. Iimi (2004), using a narrower set of data (from 1997 to 2001) for 51 countries finds decentralization as instrumental for economic growth. Thiessen (2003), using a panel of developed OEDC countries conclude that there is an optimal level of decentralization over which no additional gains are obtained from decentralizing.

In the light of these results, some other empirical studies have tried to find the channel through which fiscal decentralization could affect economic growth. The impact that decentralization could have in the level of inflation has been found insignificant (Treisman (2000), Rodden and Wibbels (2002)). MartinezVazquez and McNab (2005) examine the impact that decentralization could have on macroeconomic stability finding a positive relation that would imply an indirect positive impact with economic growth.

Nevertheless, The literature about fiscal decentralization has not traditionally looked at the impact that it may have on the composition of public expenditures. Only some recent studies address this issue. Arze , Martinez-Vazquez and McNab (2005) model and test the hypothesis that higher levels of fiscal decentralization increase the shares of consumption expenditures in the public budget (in particular, they refer to publicly provided private goods). They estimate a model from a panel data set of 45 countries and 28 years and find strong evidence of the hypothesis, especially for developing countries. Faguet (2004) analyses the effects of the process of decentralization in Bolivia at the local level, 
and finds that the functional composition of public expenditure changes with decentralization to a more efficient allocation.

\section{Theory}

As commented above, in principle central government expenditure should be more productive to local or regional governments so long as returns are at least slightly increasing. The justification of the case of decentralized public expenditure -or decentralized levels of government in general- should come justified by a counterbalancing source of efficiency that imposes any kind of advantage to the regional or local authority in comparison to the central government.

Faguet (2004) describes a first theoretical approach to the problem made by Tiebout in 1956, that develops a model in which heterogeneous individuals move costless among localities that offer different levels of provision of a public good. The assumptions of perfect population mobility and fixed governments behaviour seemed too unrealistic. Oates (1972) model a central government that produces a common level of public good for all localities while local government can tailor public spending to local tastes, in a world with heterogeneity in tastes and spillovers. Oates' justification of the existence of decentralized countries depends largely on the assumption of uniform provision of public goods by the central government.

This assumption has been relaxed lately with the introduction of voting rules for distributing expenditure. Lockwood (2002) only needs to assume equal cost sharing in a country with heterogeneous individuals among regions to show that resources would be allocated inefficiently in a centralized country. Besley and Coate (2003) reach a similar conclusion by allowing for heterogeneity of tastes within a region, modelling public expenditure under centralization as determined by a legislature of locally elected representatives. Rubinchich (2005) also relies on inefficiency of voting rules and centralized taxation to model an environment in which the central authority would find it more efficient to allocate some expenditure decisions to local governments. She proves that it is not necessary the existence of asymmetry in policy tools or in information access available to different levels of government to model a strictly welfare improving environment under decentralization. The mechanism is that heterogeneity creates conflicts between different regions that are not efficiently solved if we cannot assume the existence of a central planner, but instead use a voting rule to decide on public policy.

Another strategy to face the problem has been proposed by Brueker (2005). He uses an overlapping generations model to show that replacing a common 
tax-burden with head tax burdens that differ between younger and older citizens, that live in different jurisdictions where the public good financed by this tax would be provided at different levels, alters the economy's level of saving enhancing economic growth. The result relies of course, in the existence of significative demographic differences among regions. Alesina and Spolaore (1997) and Alesina, Baquir and Easterly (1999) justify with the heterogeneity of the population, the necessity to compute the optimal number of countries or economic jurisdictions.

Panizza (1999) internalizes the selection of the optimal level of decentralization in a model with distance-sensitive individuals and one public good. This optimal level depends positively on taste heterogeneity, democracy, income per capita and country size. The introduction of the level of democracy obeys to his assumption that the central government utility depends on a proportion of a central planner combined with a proportion of the outcome from voting rules.

However, none of the above studies address the impact of fiscal decentralization on the composition of public expenditures. We have found basically to main approaches taken to explore the problem ${ }^{4}$. The first one developed by Faguet $(2002,2004)$ assumes heterogeneous preferences among regions that are accurately capted by local governments when distributing public expenditure, while central government ascertains the exact preferences of locals with a given probability while outside this probability may lie in any other distribution of public goods. On the other hand, the central government has a cost advantage. Faguet (2004) just describes the relations between the parameters that make preferred a decentralized system, while in Faguet (2002) the author develops a cooperative game in which the local government chooses to relay information on local needs to the centre and bargaining over the allocation of public goods in a central asamblea, or remain decentralized.

The second approach, described in Arze et al (2005), is the one that better fits the purpose of our study. They extend the representative median-voter model described in Panizza (1999), which a model that uses a distance-sensitive utility function to count for the heterogeneity of the individuals. The model assumes that individuals are uniformly distributed along the country area and that the utility obtained from any given public good is decreasing on distance to the middle of the country or the region that provides it.

We will develop a version of the model described by Arze et al. (2005), introducing two main modifications: first, we assume that only one of the public goods allows for a distance-dependent utility to the population (public current expenditure), while all individuals perceive homogeneous utility from the second

\footnotetext{
${ }^{4}$ There are also some interesting studies that analyse the demand of certain types of expenditure under decentralization, among them Falch and Rattso (1997) and Gertham, Sogaard, Jonsson and Andersson (1992).
} 
public good (public capital expenditure). The second involves that we relax the assumption that regional governments only can invest their budget in one of the public goods. On the contrary we consider that both levels of government distribute their budget among both types of public goods ${ }^{5}$. The purpose is to reflect on the model the two options that every public administration faces while distributing its public budget: current expenditure and public capital. We assume that the population is not distance-sensitive to the jurisdiction that provides the capital, since we claim that this kind of behaviour is more likely to appear towards current expenditure ${ }^{6}$. We assume also that the relative price that the decentralized governments pay for the distance-sensitive public good is higher and increasing compared to the price paid by the central government, so as to include scale effects.

We assume population $\mathrm{N}$ uniformly distributed along a country with area A and $\mathrm{J}$ regions. Each agent consumes three types of goods: K, a homogeneous public good whose perceived utility is identical among individuals, a public good whose perceived utility depends on the distance to the middle of the jurisdiction that provides it, G, and finally a private good, C. We assume an exogenous level of centralization, $\theta$, which is equal to the fraction of public expenditure provided by the central government. Our purpose is to associate capital expenditure and current expenditure to $\mathrm{K}$ and $\mathrm{G}$ respectively. If $\mathrm{k}, \mathrm{g}$ and $\mathrm{c}$ define $\mathrm{K}, \mathrm{G}$ and $\mathrm{C}$ in per cápita terms respectively, the utility function of individual ' $\mathrm{i}$ ' could be defined:

$$
U=k_{i}^{\gamma} g_{i}^{\left(1-\alpha\left(\theta x_{i c}+(1-\theta) x_{i j}\right)\right)} c_{i}^{\beta}
$$

where $x_{i c}$ is the distance from individual ' $\mathrm{i}$ ' to the middle of the country and $x_{i j}$ represents her distance to the middle of the region where she lives. The parameter $\alpha,(0<\alpha<1)$, measures preference heterogeneity. Preferences become more homogeneous as $\alpha$ approaches to 0 .

The type and quantity of each public good are decided democratically by the median voter $\left(\operatorname{med}^{k}\right.$, med $\left.^{g}\right)$. With the purpose of avoiding problems related to simultaneous multidimensional voting, we assume that individuals vote on one issue at a time and that they have separable preferences. We also introduce the

\footnotetext{
${ }^{5}$ We omit the Samuelsonian pure public good defined in Arze et al (2005), and introduce public capital instead to focus our attention in the relationship between capital and current expenditure.

${ }^{6}$ We claim that public current expenditure is more likely to present a distancerepresentativeness in the perceived utility of the consumer that public capital expenditure. For example, in a public university the capital expenditure would be represented by the buildings and the general equipment and the current expenditure would be the one translated directly to the academic activities. Is in this one in which the users may perceive a difference when it is provided by local authorities, more sensitive and better informed about the specific educational needs of the region.
} 
assumption that both levels of the government have to offer the same proportion of every type of public good ${ }^{7}$.

Public spending is finance by a lump-sum tax 't' paid by every individual on an identical income y. It is also assumed that the number of voters is large enough so that the space can serve as a proxy for the voters, and the country size area is normalized to one. There is no possibility of free-ridding in this environment, so the representative agent would face a budget constrain:

$$
y=t+c=k+g^{\frac{1}{\theta}}+c
$$

The price of public capital is normalized to one while the price of 'g' depends negatively on the level of decentralization. The maximization problem of the representative agent subject to the budget constraint generates the following demand functions:

$$
g_{i}=\left[\frac{\left(1-\alpha\left(\theta x_{i c}+(1-\theta) x_{i j}\right)\right) \theta y}{\left(1-\alpha\left(\theta x_{i c}+(1-\theta) x_{i j}\right)\right) \theta+\gamma+\beta}\right]^{\theta}
$$

and

$$
k_{i}=\frac{\gamma y}{\left(1-\alpha\left(\theta x_{i c}+(1-\theta) x_{i j}\right)\right) \theta+\gamma+\beta}
$$

Given symmetric preferences, the quantity preferred by the median voter is located a distance equal to the 'median distance to the median'. For a country with area $\mathrm{A}$, the median distance to the media is $\mathrm{Ax} / 4$. Let $\left(1-\alpha\left(\theta x_{i c}+(1-\right.\right.$ $\left.\left.\theta) x_{i j}\right)\right)>0, x_{m c}^{m}$ be the median distance to the country median and $x_{m j}^{m}$ be the median distance to the region median. We can express then the per capita quantities provided at equilibrium as:

$$
g_{m}^{*}=\left[\frac{\left(1-\alpha\left(\theta x_{m c}^{m}+(1-\theta) x_{m j}^{m}\right)\right) \theta y}{\left(1-\alpha\left(\theta x_{m c}^{m}+(1-\theta) x_{m j}^{m}\right)\right) \theta+\gamma+\beta}\right]^{\theta}
$$

\footnotetext{
${ }^{7}$ This assumption simplifies a lot the structure of the model but may be thought as a bit rigid. A reason in favour of it may be that any functional level of competencies that a region may achieve, usually includes both current and capital expenditure (for example a region that have the competencies to run the public health system, would have to assume both current and capital expenditures attached to it). The main point against the assumption is that not all the functional categories of expenditure have the same share of current to capital expenditure. It is relativelly compatible with our data (see figure 3).
} 
and

$$
k_{m}^{*}=\frac{\gamma y}{\left(1-\alpha\left(\theta x_{m c}^{m}+(1-\theta) x_{m j}^{m}\right)\right) \theta+\gamma+\beta}
$$

From the derivatives of these expressions, we can actually compute the relationships that we were looking for. Given a sufficiently high level of centralization, $\theta>\theta^{*}, 8$ a decentralization process will induce lower levels of public expenditure in the homogeneous public good and higher levels of provision of the heterogeneous public good, since $d g_{m}^{*} / d \theta<0$ and $d k_{m}^{*} / d \theta>0$. Once this economy is 'too decentralized' and $\theta$ descends under $\theta^{*}$, the negative effects caused by the increasing costs of decentralization overcome the benefits from a closer provision of public goods and both effects reverse.

That may be explained, because in a more decentralized country there will be more utility for the individuals from the consumption of heterogeneous public goods, that will make the demand for this kind of expenditure to increase, producing also a substitution effect that lowers the demand for the homogeneous good. All this as a cost of paying an increasing price for the heterogeneous public good. This situation dies out progressively as we reach $\theta^{*}$.

We may also observe that, in the same centralized economy with $\theta>\theta^{*}$, total public expenditure increases with decentralization $\left(d\left(g_{m}^{*}+k_{m}^{*}\right) / d \theta<0\right)$, which is produced by a substitution effect also on the consumption of the private good, c.

The median voter framework used to model the relationship between public expenditure and decentralization ignores the effects -described in the literature review- that public capital expenditure may have on multifactor productivity. Those effects may not be properly taken into account by the decision maker, and that could lead to a non-efficient allocation of public expenditure under decentralization. If higher levels of public capital expenditure produce a positive externality on productivity growth -enhancing, for example, technical changewe should be more sceptical about the benefits of decentralization. To shed some more light in this issue, we test for cointegration of TFP and regional capital expenditure.

\section{Data description and sources.}

\subsection{Sources of data.}

$$
{ }^{8} \theta^{*}=-\frac{1}{2} \frac{-1+\alpha x_{j}}{\alpha\left(x_{c}-x_{j}\right)}
$$


The model is estimated for a balanced panel of the seventeen Spanish regions over the period 1984-2003. The sample begins in 1984 because, although the firsts Statutes of Autonomy were aproved in 1979, 1984 was the first year in which all the regions started to develop their full activity . We use data until 2003 due to data availability.

The two Autonomous cities, Ceuta and Melilla, have been excluded from the Sample. This decision was taken based on three main reasons: First, the unsignificant size of these two small cities in comparison with the other regions. Second, because of the particular patterns of behaviour of their public bodies due to their different political and fiscal status, and finally, because of the difficulty to get data from the period previous to their current Statute of Autonomy, aproved on 1995 .

\subsection{Dependent variable.}

The dependent variable is the ratio of capital to total public expenditure of the Spanish regional governments. Previous empirical studies have used this ratio as an explanatory of factors productivity (Devarajaan, Swaroop and Zou (1996)), but it has been rarely used as a dependent variable to be explained (Diaz-Cayeros, McElwain, Romero and Siewierski (2002), Sturm (2001)).

The use of a ratio allows us to observe the importance that governments give to capital goods relatively to consumption goods independently of changes in the volume of total expenditure induced by other factors. The main shortcoming is, precisely, the dependency on the volume of total expenditure. The ratio may be sensitive to extraordinary changes on total expenditure, for example, because of a readjustment on the public debt. We will see later (in figure 3) that such a situation may appear slightly for the central government in the year 1987, but rarely may be considered for the regional government, because of the minor level of autonomy to run financial operations.

The ratio is built from data on total regional public expenditure and public regional capital expenditure, obtained from the BADESPE ${ }^{9}$ database, elaborated by the Instituto de Estudios Fiscales (Fiscal Studies Institute), dependent of the Ministry of Economics of Spain. This database contains economic data from the Spanish public sector, in particular fiscal variables, such as taxes, other revenues or budget.

\footnotetext{
${ }^{9}$ http://www.estadief.meh.es/
} 


\subsection{Explanatory variables.}

The decision of choosing a variable that measures precisely the level of decentralization on fiscal issues may be quite controversial. Martinez-Vazquez and McNab (2003) describe how ideally a panel data set of measures of fiscal decentralization would be able to quantify the activities of sub national governments resulting from their independent decisions, what would mean, for example, discriminating those expenditures that are under the effective control of the central government as central government activities, even if they are carried out by other level of the public administration. That would mean that not only the relative volume of public funds distributed by subnational authorities do determinine how decentralized an economy is. We should ideally take also into account the level of autonomy with which those funds are managed.

Unfortunately, we cannot address these issues with the available data. The literature has adopted the standard measure of fiscal decentralization described by Oates (1972) based on local o subnational to total public expenditure ratio ${ }^{10}$. It seems reasonable to us to assume that the level of fiscal automy is correlated to the share of public resources managed by a regional government.

The level of decentralization is built then, as the ratio of per capita regional expenditure to per capita central government expenditure, also from the data of the yearbook 'Presupuestos de las Comunidades Autonomas'.

\begin{tabular}{|c|c|c|c|c|}
\hline Variable & label & Definition & Units & Source \\
\hline capital share & сар & $\frac{\overline{\text { regional capital } \exp }}{\text { total } \exp }$ & Fraction $(0-1)$ & Badespe \\
\hline fiscal decentralization & dec & $\begin{array}{l}\text { regional per capita public exp } \\
\text { national per capita public exp } \\
\end{array}$ & Fraction $(0-1)$ & Badespe/ INE \\
\hline capital stock per capita & kstockpc & $\frac{\text { stock of capital of the region }}{\text { population of the region }}$ & Miles E. (const.p., b=1986) & IVIE/NE \\
\hline central gov. capital exp & cgcape & capital expenditure run by central government & Million Euro., current prices & INE \\
\hline population & pop & Total region midyear population & Million units & INE \\
\hline GDP per capita & GDPpc & GDP in current prices per capita & Miles Euro., current prices & INE \\
\hline
\end{tabular}

The selection of the rest of control variables has been largerly based on studies focused on determining the determinants of public capital spending as well as on Martínez Vázquez and Mc Nab (2003), keeping in mind that all those studies use country data and some of the variables that they include would not fit in our regional panel data (budget deficit or industrialized country dummy, for example).

\footnotetext{
${ }^{10}$ It is used for example by Zang and Zou (1998), Martinez-Vazquez and McNab (2003), Iimi (2004), Jin, Qian and Weingast (2005) among others.
} 
We do include population and per capita GDP. Changes in population could be a determinant of the necesities of public capital relative to publicly provided consumption goods. It also might explain the possible scale effects existing in particular kinds of investment via the marginal cost of additional users, in the case of "pure" public goods. The variable population has been included as an approximation of labor force supply in many studies that examine the productivity of public capital (Ramirez (1998) and Everaert and Heylen (2001)).

It may be expected that the productivity of public capital changes with the level of production. In principle a less wealthy population is expected to have stronger prefereces for public investment, to supply the lack or the minor productivity of private capital. GDP per capita has been frequently used as a control to explain growth (Barro (1991), other fiscal variables (Kneller, Bleaney and Gemell (1999)) and it is used in all the consulted studies identifying determinants of public capital expenditure ${ }^{11}$. Both variables have been obtained from the INE database.

In addition we include capital stock per capita and central government capital expenditure. The first controls for the necessities of more capital, since a region with a smaller stock of capital is expected to have larger marginal returns to capital and therefore, a higher demand for public capital expenditure. Randolph, Bogetic and Hefley (1996) defend the inclusion of the actual stock of public infrastructure as a variable determining its current level of spending. They find that their results very sensitive to the alternative variables used to measure the stock of infrastructure, since there were no inventory of stock of public capital for their set of countries. This does not represent a problem for us, since we count with an inventory of public capital for the Spanish regions at constant prices.

Central government capital expenditure tries to control for the policy of the central government regarding public capital, and the substitution effect that could induce to regions. Data on total public capital stock on the Spanish region are available in the IVIE (Instituto Valenciano de Investigaciones Economicas) website. Data on central government capital expenditure were obtained from the INE database.

${ }^{11}$ Sturm (2001), De Haan, Sturm and Sikken(1996) among others. 


\begin{tabular}{||c||c||c||c||c||c||}
\hline \hline & $\mathrm{N}$ & mean & St. Deviation & minimum & maximum \\
\hline \hline cap & 340 & .2720935 & .1294949 & .0206426 & .6145927 \\
\hline \hline dec & 340 & .3569552 & .2306555 & .0502049 & 1.247196 \\
\hline \hline kstockpc & 340 & 21953.01 & 15809.4 & 10038.39 & 108779.6 \\
\hline cgcape & 340 & 1379756 & 601462.2 & 78500 & 2136850 \\
\hline pop & 340 & 2333307 & 2009264 & 256753 & 7606848 \\
\hline GDPpc & 340 & 9512.318 & 4057.546 & 2390.98 & 20385.23 \\
\hline \hline & & & & & \\
\hline
\end{tabular}

Table 1: Summary Statistics.

\subsection{Evolution over time.}

The process of decentralization of public financing in Spain starts with the approval of the Spanish Constitution of 1978. The national territory is divided into seventeen regions or Autonomous Communities (NUTS 2 using the nomenclature proposed by the European Commission) and two Autonomous cities, Ceuta and Melilla.

The level of competencies of the regions is not symmetric, and the process of constitution of all the regional governments finishes in 1983. Simultaneously to this process of political adaptation to the new Constitution, occurs the most important increase of public spending. Total public spending moved to represent a $27.51 \%$ of GDP in 1976 to $44.10 \%$ in 1985 . This growth has continued later but at a slower pace to lie around $54 \%$ in 2000 .

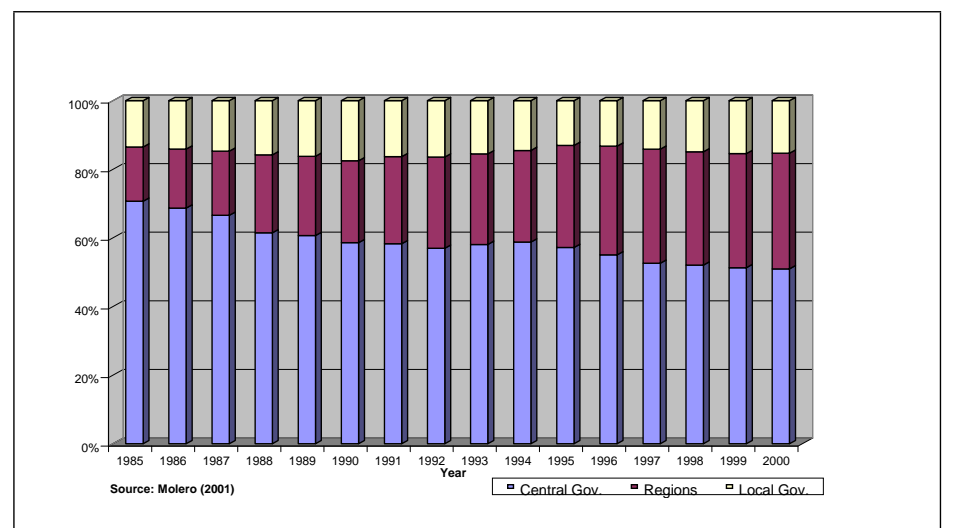

Figure 1: Shares of Public Expenditure by level of administration 
Figure 1 show how a progressive decentralization of public expenditure has been taking place in Spain since the development of the regional governments. This process has affected mainly the regional level, since local public expenditure has only increased his share over total expenditure 2.5 percentage points in fifteen years, while the regional level has passed to represent $33.9 \%$ of total public expenditure in 2000 while in 1985 it represented only $15.8 \%$.

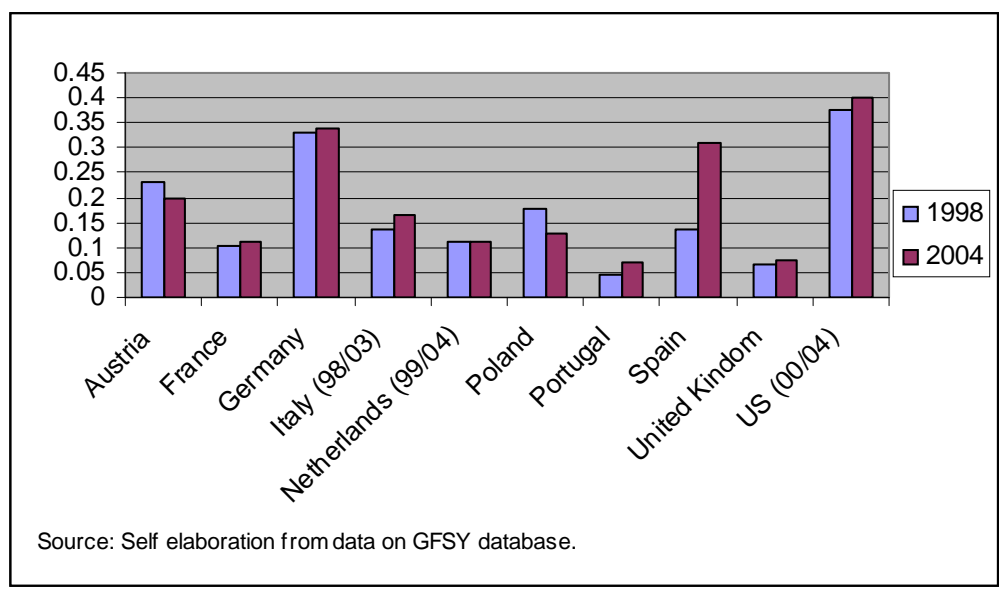

Figure 2: Comparative evolution of fiscal decentralization.

Figure 2 shows the share of non-central government expenditure to total public expenditure in several countries ${ }^{12}$. It shows that the process of decentralization that Spain has suffered is not a general pattern of behavior of the countries on its environment. The level of this ratio has raised in the last years to reach a situation comparable to federal countries like the US or Germany.

But this process has not been homogeneous. The reason is that the Spanish Constitution discriminates the level of competencies of the different regions. The Constitution consider two groups. The first one is the so called 'historic nationalities ${ }^{13}$, or regions with high level of competencies. Those regional governments have a higher level of independency. The second group is made of the ten remaining regions ${ }^{14}$ (and the two autonomous cities) that in principle assume a lower level of competencies.

\footnotetext{
${ }^{12}$ The data are extracted from the Government Finance Statistics Yearbook database, elaborated by the IMF. Consolidated central government expenditure includes public expenditure carried out by the Social Security organism. That explains the difference of this ratio with figure 1. The database does not provide data to compute the ratio before 1998 .

${ }^{13}$ Andalusia, Canary Islands, Catalonia, Galicia, Navarre, Valencia and Bask Country.

${ }^{14}$ Aragon, Asturias, Baleares, Cantabria, Castile-La Mancha, Castile and León, Extremadura, La Rioja, Madrid and Murcia.
} 
In practice, the regions with high levels of competencies experienced a higher level of decentralization in the beginning, but the differences have been reduced as long as the decentralization process described above has been taking place. That can be seen in the evolution of the ratio that we have chosen to measure the level of fiscal decentralization.

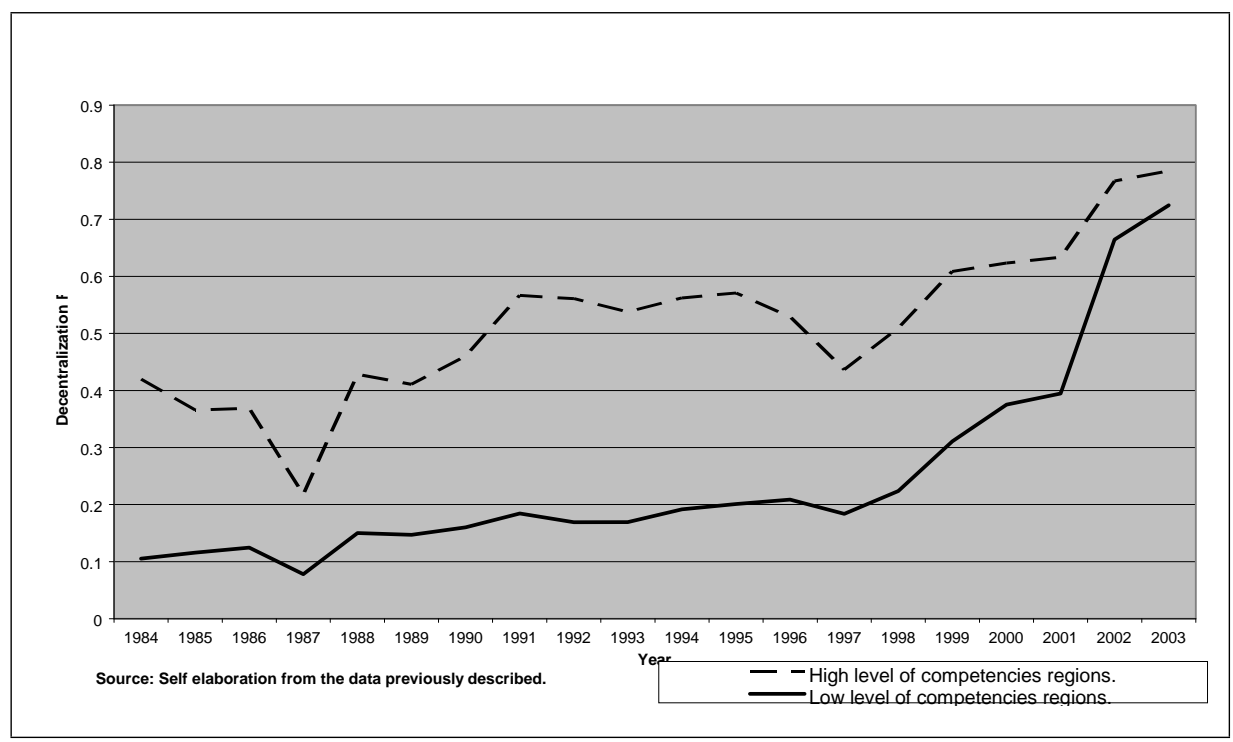

Figure 3: Decentralization Measure

As described above, this ratio formed as a coefficient of per capita public expenditures between the regional and central government, may present some weaknesses, for example the fact that depends also on expenditure policies run by the central government ${ }^{15}$. However, to our purpose of intra country analysis that does not represent a great issue, since the denominator is common for all our regions.

The increase on the proportion of public spending run by regional movements has affected also the distribution of public regional spending among the different economies categories. The regions have augmented the share of current spending, devoting a minor part of their funds to increase their stock of capital:

\footnotetext{
${ }^{15}$ For example, a great increase of Central Government Expenditure in 1987 due to financial operations after the entrance of Spain in the EU has induced an 'abnormal' decrease of the value of the ratio for all regions in this year.
} 


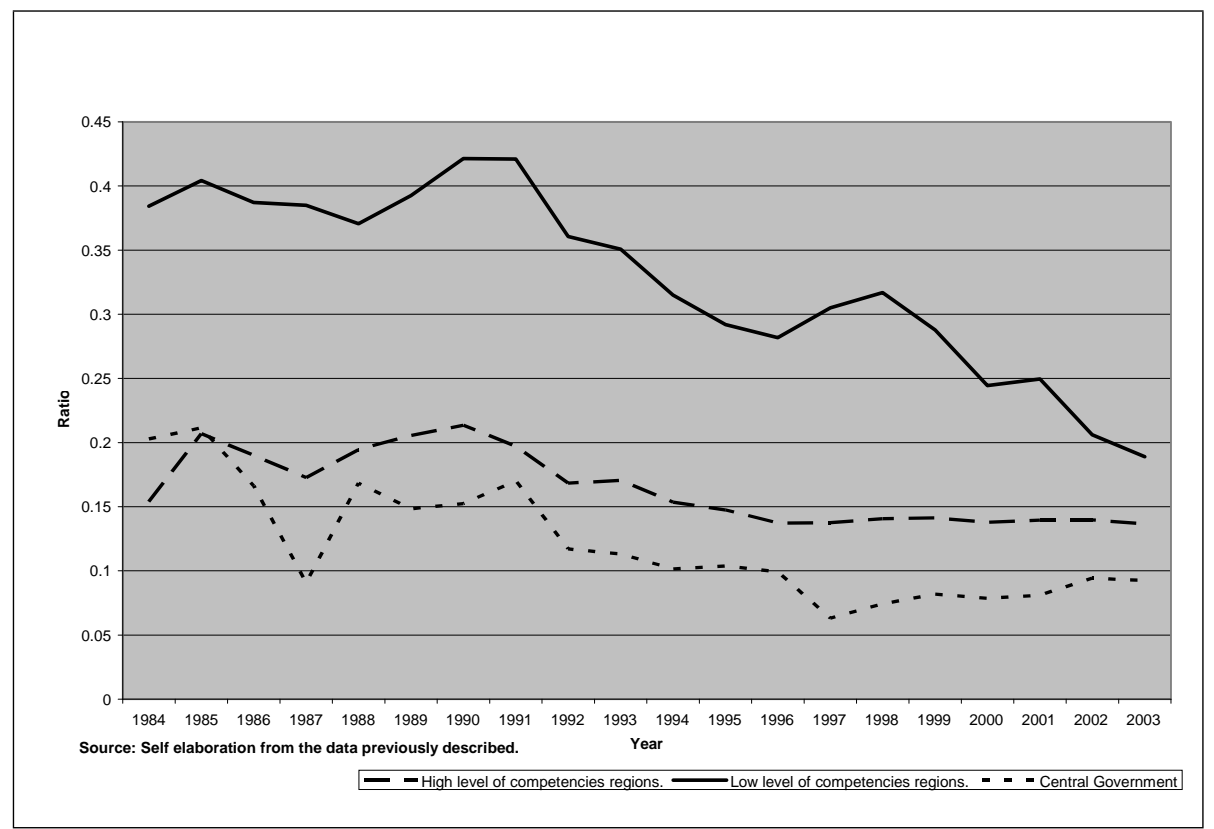

Figure 4: Ratio Capital to Total Expenditure.

One could think that this situation could be induced by a certain reallocation of competencies between the central and regional governments. However we can check how the Central Government has not increased its share of capital expenditure, but on the contrary has also slightly decreased it. The fall on capital share of public expenditure is clearly more relevant on the regions with low levels of competencies, which are also those that have suffered a deeper process of decentralization. We want to prove in the paper that the later is a consequence of the process of decentralization.

The graphs presented in appendix I make a deeper analysis on which are the functional categories in which the higher level of decentralization takes place, in other words, which are the areas in which regional government gain more power. The category 'Social Public Goods' -he nomenclature of the fuctional clasification used by the Spanish 'Ministerio de Economía y Hacienda '- is the main area of decentralization for the regions with low level of competencies as well as the main component of the public budget. In 1994 it represented around $20 \%$ of the budget of the regions with low levels of competencies and $55 \%$ of the groups of more autonomous regions, while in 2003 it already represented more than $60 \%$ of the total budget in both groups. This category includes the two groups of public policies that have experienced a substantial change of competency from central to regional governments: Health and Education. The graphs also reveal how simultaneously there has been a change in the share of capital and current expenditure devoted to this category. 
Other functional categories that have experienced a significant level of decentralization have been 'Social Security and Promotion ', 'Economic regulation of Productive Sectors ', 'General Public Services ' and 'Economic Public Goods'. Among them, only the expenditure devoted to 'General Public Services ' has increased its share of capital expenditure simultaneously to this decentralization process. We should also comment that the per capita level of expenditure for some those categories is quite similar between regions with high and low levels of competencies. Thus, there are some categories of expenditure in which there were no significant differences on the level of competencies.

\subsection{Sources of Revenues.}

Given the great heterogeneity of competences that have been progressively assumed by the different regions, it has been necessary the development of a system able to be adapted to this dynamic environment. The system provides multiple tools to compute the fair amount of the public funds that should be allocated to every region, in proportion to the competencies that it assumes. But the diversity of the Spanish system goes further than this, since two regions have a particular regime of financing called 'Régimen Foral ', that we will introduce also.

The system for the remaining 15 regions started to work regularly in 1987 . Before the system was being progresively established and some of the transfers from the central government were the result of a negotiation process between both levels of government. From 1987 onwards, the general system is revised every five years to increase the power of decisions to regions. Many of the rules to compute the finance necessities that were set for the first period (1987-1991) are still valid.

The difference introduced progressively is the source of this financing. Initially, the great majority of the funds were provided directly by the central government according to these rules (Participation on the Revenues of the State or PRS). But the revisions for the periods 1992-1996 and mainly 1997-2001 give some taxing power to the regions.

In the period 1992-1996, the collection of some taxes ${ }^{16}$ is transferred from the central government to regions. In addition regions perceive directly $15 \%$ from the income tax, collected by the central government. The amount collected is subtracted from their PRS, which means that so far that is only a change of procedure, but not really of autonomy. In the period 1997-2001 regions gain a limited normative capacity about the taxes that they collect as well as over their own portion on the income tax, that moves from $15 \%$ to $30 \%$ (progressively for the regions with low level of competencies, as they assume

${ }^{16}$ The more important ones are taxes on wealth, gifts, inheritance and gamble. 
complete competencies on education). They also get the capacity of issuing new taxes. From 2002 the system includes a higher share of taxes collected by the central government and will not be revised after five years, but considered permanent.

This system is completed by some complementary sources of revenues. The Social Security funds are collected by an autonomous organism ${ }^{17}$ that will redistribute them among regions and central government according to their expenditure needs and competencies, to finance public expenditure in Health policies.

Navarra and Vasc Country have a different system as a consequence of some privileges that existed previously to Franco's dictatorship. The regional government in Navarra and subregional levels of government in Vasc Country have the competence of collecting practically all the taxes. They also have a limited normative capacity over them. (footnote) Then, they have to transfer to the central government an amount representing the cost of the services provided in those regions. To compute this volume, it is taken into account the cost of these services, the population of both the region and the whole country and also both Production levels.

All the regions have a very limited capacity of incurring into budget deficit, which is monitored by the central government. In appendix [2] we analyze the evolution of the different sources of income in the different regions in the period 1986-2001. The data have been collected from the database of the "Instituto de Estudios Fiscales".

\section{Empirical Analysis}

\subsection{Model Specification and Econometric Issues.}

In this section we test the hypothesis that decentralization affects the distribution of public expenditure at the regional level. For that, we estimate an equation in which the dependent variable is the ratio of capital expenditure to total expenditure of the regional government, and as explanatory variables we introduce decentralization level . Two alternative sets of control variables that could affect the composition of public expenditure have also been included. The first set includes per capita stock of capital and the public capital expenditure made by the central government. The second adds GDP per capita and population as suggested in Arze et al. (2005).

The dependent variable, cap is defined as the ratio of capital expenditure to total public regional expenditures. The purpose is to check the sensibility

\footnotetext{
${ }^{17}$ Tesorería General de la Seguridad Social.
} 
that increases in decentralization levels may have on the composition of public expenditure, and in particular on the proportion of capital to current spending on regional governments. In terms of the explanatory variables, our main interest lies on decentralization, dec, measured as the share of per cápita regional public expenditure to per capita total public expenditure. A matrix X of control variables should include population, budget balance and GDP per capita:

$$
\operatorname{cap}_{i, t}=\alpha_{i}+\alpha_{0}+\alpha_{1} d e c_{i, t}+\alpha_{2} X_{i, t}+u_{i, t}
$$

Some discussion has to be made on this specification, since the dependent variable is a fraction constrained to lay in the interval $(0,1)$. In such cases very often the literature suggest the use of a logistic transformation. Papke and Wooldridge (1996) instead suggest quasi-likelihood estimation methods for models in which the dependent variable is bounded. Problems related to these models arise when it is possible to observe values closed to the boundaries. Given that this is not the case of our variable, we do not consider necessary to apply any transfromation to the model to deal with this issue.

We report both fixed effect estimation and random effect estimation results of the AR model for both set of variables. The comparison and the validity? of both estimations are related to the (unobserved) individual effect $\alpha_{i}$. As Wooldridge (2002) points out, the discussion does not regard whether it should be properly viewed as a random variable or as a parameter to be estimated, but the key issue involving $\alpha_{i}$ is whether or not is correlated with the observed explanatory variables $X_{i, t}$ and $d e c_{i, t}, \mathrm{t}=1,2 \ldots \mathrm{T}$. Both estimation methods, fixed effects and random effects, do assume strict exogeneity of the explanatory variables conditioned on $\alpha_{i}$. But random effect methods assume in addition ortogonality between $\alpha_{i}$ and the explanatory variables, while for fixed effects analysis $E\left(\alpha_{i} / x_{i}\right)$ is allowed to be any function of $x_{i}$.

We do not suspect of endogeneity of any of the explanatory variables, but the presence of correlation between the individual effect and any of them does not seem unplausible. In such a case, the random effects estimator would be unconsistent. On the other hand, when the individual effect and the explanatory variables are in fact orthogonal, the fixed effects methods are imposing additional restrictions on the coefficients that would normally lead to larger variances of the estimations. The Hausman (1978) test does precisely arrow a conclusion about the correlation between the individual effect and the explanatory variable from the difference between the random effects and fixed effects estimates. The implementation of the Hausman test in our specific problem reveals that we cannot reject the null hypothesis of no correlation in all cases. 
The random effects models are estimated using feasible GLS. The fixed effects models are estimated using pooled OLS on the standard within transformation $^{18}$. Because of the lengh of the sample and the nature of the variables, we suspect a priori that serial correlation may be a problem. The Bhargava, Franzini and Narendranathan (1982) test statistic suggest that the error term of the specification may be $\operatorname{AR}(1)^{19}$. The autoregressive parameters reported are computed from the Durbin-Watson statistics ${ }^{20}$.

In colums (1) and (4) we report the feasible GLS estimation of the first differenced model. The estimators on the first-differenced model may add some more valuable information. Its comparison to the fixed-effects estimation hinges on the assumptions about the idiosyncratic errors, $\mathrm{u}_{i t}$. In particular, the within estimation is more efficient when the errors are serially uncorrelated, while the first-differences ir more efficient if $\mathrm{u}_{i t}$ follows a random walk. In this case the thruth is likely to lie somewhere in between. Wooldridge (2002) also suggests that the comparison between both estimators may serve us to arrow conclusions about the exogeneity of the explanatory variables, since in the presence of correlation between $\mathrm{x}_{i t}$ and $u_{i t}$ both estimators have different probability limits.

\subsection{Estimation results}

Table [2] shows the results of estimating equation [number], using two alternative sets of control variables and three possible estimation methods. Firstly we consider the linear fixed effects regression including the first differences of the variables considered. Later we setup an AR model estimated both by random and fixed effects:

\footnotetext{
${ }^{18}$ that consist on substacting from the original equation " $y_{i t}=\alpha_{i}+x_{i t}+u_{i t}$ " the averaged equation " $\bar{y}_{i}=\alpha_{i}+\bar{x}_{i}+\bar{u}_{i}$ " and yields $\ddot{y}=\beta \ddot{x}_{i t}+\ddot{u}_{i t}$, where $\ddot{y}_{i t}=y_{i t}-T^{-1} \Sigma_{t=1}^{T} y_{i t}$, $\ddot{x}_{i t}=x_{i t}-T^{-1} \Sigma_{t=1}^{T} x_{i t}$ and $\ddot{u}_{i t}=u_{i t}-T^{-1} \Sigma_{t=1}^{T} y_{i t}$.

${ }^{19}$ The estimated statistic is 0.77 for the complete model and 0.76 for the model without population and GDPpc as explanatory. See Baltagi (2005) for more details.

${ }^{20} 1-\mathrm{dw} / 2$, where $\mathrm{dw}$ is the Durbin-Watson $\mathrm{d}$

statistic
} 


\begin{tabular}{|c|c|c|c|c|c|c|}
\hline & (1) & (2) & (3) & (4) & (5) & (6) \\
\hline & First Differences & $\begin{array}{r}\text { Fixed Effects } \\
\text { (AR1) }\end{array}$ & $\begin{array}{c}\text { Random Effects } \\
\text { (AR1) }\end{array}$ & First Differences & $\begin{array}{r}\text { Fixed Effects } \\
\text { (AR1) }\end{array}$ & $\begin{array}{c}\text { Random Effects } \\
\text { (AR1) }\end{array}$ \\
\hline Fiscal decentralization & $\begin{array}{r}-0.10169^{* * * *} \\
(.0418)\end{array}$ & $-0.1502 * * *(.0395)$ & $\begin{array}{r}-0.16041^{* * * *} \\
(.0374)\end{array}$ & $-0.09471 * *(.0415)$ & $-0.1994 * * *(.0299)$ & $\begin{array}{r}-0.18372^{* * * *} \\
(.0369)\end{array}$ \\
\hline $\begin{array}{c}\text { Capital stock per capita } \\
(10 \mathrm{e} 3 \mathrm{E})\end{array}$ & $0.0081 * *(.0092)$ & $0.0217^{* * *}(.0081)$ & $0.0171 * *(.0077)$ & $0.0061 *(.0084)$ & $0.0195^{* *}(.0079)$ & $0.0174 *(.0077)$ \\
\hline $\begin{array}{c}\text { Central Government } \\
\text { capital spending } \\
(10 \mathrm{e} 6 \mathrm{E})\end{array}$ & $-0.0082 \quad(.0069)$ & $-0.0186 * *(.0075)$ & $-0.0166^{* *}(.0069)$ & $-0.0091(.0069)$ & $-0.0219 * * *(.0074)$ & $-0.0256^{* * * *}(.0062)$ \\
\hline Population (10e6) & $0.0895(.0919)$ & $0.0847(.0572)$ & $-0.0182^{* *}(.0088)$ & & & \\
\hline GDP per capita (10e3 E) & $0.0035(.0101)$ & $-0.0081 * * *(.0031)$ & $-0.0067^{* * *}(.0023)$ & & & \\
\hline Observations & 323 & 323 & 340 & 323 & 323 & 340 \\
\hline \multicolumn{7}{|c|}{$\begin{array}{l}* * * \text { Significant with a } 1 \% \text { confidence interval } \\
* * 5 \% \text { confidence interval } \\
* 10 \% \text { confidence interval }\end{array}$} \\
\hline
\end{tabular}

Table 2: Estimated Coefficients Composition of Public Expenditures.

Results do undoubtedly support the hypothesis that capital expenditure depends on the level of decentralization. The coefficients estimated for the variable 'fiscal decentralization' are negative and highly statistically significant in every model. The values for the coefficients vary from 0.09 to 0.19 , which means that an increase in the level of decentralization of one percentage point would induce a decrease on the ratio of capital to total regional public expenditure of at least $0.09 \%$. The sign and the significance of the effect seems quite clear.

This result is consistent with the one obtained by Arze et al. (2005), in terms of significancy and sign of the coefficients. However, their estimated values are not comparable since they use as dependent variable a proxy for public consumption constructed as the fraction of public education and health on total public expenditure ${ }^{21}$ ?. They estimate a value for the coefficient accompanying Dec from 0.24 to 0.38 . They estimate an increase on public consumption around $0.3 \%$ while we estimate a decrease on public capital expenditure around $0.15 \%$, as a response to the identical one-percentage point increase in decentralization measure. De Haan, Sturm and Sikken (1996) reach a similar conclusion using a test on a panel of 22 OECD countries for the period 1980-1992, although their measure of fiscal centralization is based on tax collection, instead of the aproach based on public expediture.

The behavior of the control variables seems more sensitive to alterations on the methodology. The influence of the level of population on the dependent variable is clearly insignificant, rejecting so the relevance of scale effects at this level.

\footnotetext{
${ }^{21}$ They also use national data for a set of 45 developed and developing countries, while we are using Spanish regional data.
} 
One could also expect a negative coefficient associated to the actual level of capital stock per capita, as an indicator that governments closer to an optimal level of capital start to deviate public spending funds from it. However, the situation could be even the contrary since the coefficient estimated associated to the level of capital stock is possitive except when the model is estimated assuming random effects, that is insignificant. That could be due to the fact that private and public investment are complementary, and the alterations to the stock of capital are in a great share due to the dynamic behavior of private investment. De Haan et al. (1996), for example, find public capital expenditure highly correlated to private investment ${ }^{22}$.

On the contrary, the coefficient attached to the public capital expenditure made by the central government shows similar behavior to that of capital stock but with negative coefficients. In this case, both types of public investment may not be complementary but substitutes and therefore an increase in public capital expenditure by the central government should push-down that of regional governments.

As for the GDPpc, it seems that poorer regions tend to spend a higher share of their budgets on capital, probably as a reflexion of their intention to catch-up the richer ones. The model in first differences find the coefficient non-significant.

\subsection{Robustness Check.}

Now we analyze the robustness of the results from the main regression shown in table 2 to some alterations in the data used. Firstly, we want to discriminate from the results the effect that could have been induced by the existence on a common business cycle. For that, we have computed the same estimations (table 2b) substituting the economic series by filtered data using the Hodrick-Prescott method. In particular, we apply the Hodrick-Prescott filter to the series capital expenditure, total expenditure and central government expenditure. Therefore, the ratios cap and dec are built from filtered data. We also apply the filter to the series central government capital expenditure, capital stock per capita and GDP per capita, while the series population remain unaltered. The findings are shown in table $2 \mathrm{~b}$. The significance of the effects that decentralization has in public capital expenditure remain robust to this alteration, althought the absolute values of the coefficients estimated are definitely different as a consequence of the filtering process.

\footnotetext{
${ }^{22}$ They estimate a coefficient of 0.076 , defining the dependent variable cap in a similar way to ours and the explanatory variable private investment as its share on the GDP.
} 


\begin{tabular}{|c|c|c|c|c|c|c|}
\hline & (1) & (2) & (3) & (4) & (5) & (6) \\
\hline & First Differences & $\begin{array}{l}\text { Fixed Effects } \\
\text { (AR1) }\end{array}$ & $\begin{array}{c}\text { Random Effects } \\
\text { (AR1) }\end{array}$ & $\begin{array}{c}\text { First } \\
\text { Differences }\end{array}$ & $\begin{array}{l}\text { Fixed Effects } \\
\text { (AR1) }\end{array}$ & $\begin{array}{c}\text { Random } \\
\text { Effects (AR1) }\end{array}$ \\
\hline Fiscal decentralization & $\begin{array}{c}-0.0693^{* *} \\
(.0289)\end{array}$ & $\begin{array}{c}-0.9383^{* *} \\
(.4350)\end{array}$ & $\begin{array}{c}-0.6293^{* *} \\
(.3361)\end{array}$ & $\begin{array}{c}-0.0537^{*} \\
(.0289)\end{array}$ & $\begin{array}{c}-1.475^{* * *} \\
(.3383)\end{array}$ & $\begin{array}{c}-0.6941^{* *} \\
(.2874)\end{array}$ \\
\hline $\begin{array}{c}\text { Capital stock per capita } \\
(10 \mathrm{e} 3 \mathrm{E})\end{array}$ & $\begin{array}{l}0.032 * * * \\
(.0053)\end{array}$ & $\begin{array}{c}0.0586 * * * \\
(.0101)\end{array}$ & $\begin{array}{l}.00635 \\
(.0039)\end{array}$ & $\begin{array}{c}0.0308^{* * *} \\
(.0053)\end{array}$ & $\begin{array}{l}0.054 * * * \\
(.0099)\end{array}$ & $\begin{array}{l}0.0068^{*} \\
(.0036)\end{array}$ \\
\hline $\begin{array}{l}\text { Central Government capital } \\
\text { spending }(10 \mathrm{e} 6 \mathrm{E})\end{array}$ & $\begin{array}{c}0.0246^{* *} \\
(.0109)\end{array}$ & $\begin{array}{c}0.379^{* *} \\
(.181)\end{array}$ & $\begin{array}{l}-0.395^{* *} \\
(.154)\end{array}$ & $\begin{array}{l}0.0142 \\
(.0108)\end{array}$ & $\begin{array}{l}0.171 \\
(.145)\end{array}$ & $\begin{array}{l}-0.3810^{* * *} \\
(.121)\end{array}$ \\
\hline Population (10e6) & $\begin{array}{l}0.0231 \\
(.0155)\end{array}$ & $\begin{array}{l}-0.0476 \\
(.263)\end{array}$ & $\begin{array}{l}-0.0283 \\
(.0029)\end{array}$ & & & \\
\hline GDP per capita (10e3 E) & $\begin{array}{c}0.0257 * * * \\
(.0069)\end{array}$ & $\begin{array}{c}-0.0471^{*} \\
(.0263)\end{array}$ & $\begin{array}{c}-0.00058 \\
(.0231)\end{array}$ & & & \\
\hline Prob $>F$ & 0.0000 & 0.0000 & - & 0.0000 & 0.0000 & - \\
\hline Observations & 323 & 323 & 340 & 323 & 323 & 340 \\
\hline $\begin{array}{l}\text { *** Significant with a } 1 \% \text { con } \\
* * 5 \% \text { confidence interval } \\
* 10 \% \text { confidence interval }\end{array}$ & nce interval & & & & & \\
\hline
\end{tabular}

Table 2b: Robustness check. Estimated Coefficients Composition of Public Expenditures. Hodrick-Prescott filtered data.

In a second check we run the original regression using data only from those regions clasified as 'with low level of competencies'. As we described before, the regions with 'high levels of competencies' show highly heterogeneus financing system and asumption of competencies, while for the ten remaining regions the rules were almost identical. In addition, this is the set of regions that have experiences a broader change on its decentralization level. The results, described in table 2c, do support the original hypothesis of the paper that decentralization have an effect on the level of public capital spending, although the levels of significance for the set of control variables is poorer. The coefficients estimated for fiscal decentralization also show slighly poorer levels of significancy. That could be a consequence of the smaller number of observations that we use in this regression. The estimated coefficients are, however, a bit larger in absolute value than those from table 2 . 


\begin{tabular}{|c|c|c|c|c|c|c|}
\hline & (1) & (2) & (3) & (4) & (5) & (6) \\
\hline & $\begin{array}{c}\text { First } \\
\text { Differences }\end{array}$ & $\begin{array}{l}\text { Fixed Effects } \\
\text { (AR1) }\end{array}$ & $\begin{array}{c}\text { Random Effects } \\
\text { (AR1) }\end{array}$ & $\begin{array}{c}\text { First } \\
\text { Differences }\end{array}$ & $\begin{array}{l}\text { Fixed Effects } \\
\text { (AR1) }\end{array}$ & $\begin{array}{c}\text { Random Effects } \\
\text { (AR1) }\end{array}$ \\
\hline Fiscal decentralization & $\begin{array}{c}-0.1546^{* *} \\
(.073) \\
\end{array}$ & $\begin{array}{c}-0.1595^{* *} \\
(.062) \\
\end{array}$ & $\begin{array}{c}-0.1465^{* *} \\
(.058) \\
\end{array}$ & $\begin{array}{c}-0.1433 * * \\
(.071) \\
\end{array}$ & $\begin{array}{c}-0.1966 * * * \\
(.051) \\
\end{array}$ & $\begin{array}{c}-0.2428^{* * *} \\
(.044) \\
\end{array}$ \\
\hline $\begin{array}{c}\text { Capital stock per capita } \\
(10 \mathrm{e} 3 \mathrm{E})\end{array}$ & $\begin{array}{l}0.0094 \\
(.012)\end{array}$ & $-0.0041(.0028)$ & $\begin{array}{l}-0.0001 \\
(.0010)\end{array}$ & $\begin{array}{l}0.0108 \\
(.010)\end{array}$ & $\begin{array}{c}-0.0055^{* *} \\
(.0023)\end{array}$ & $\begin{array}{l}0.0014 \\
(.0012)\end{array}$ \\
\hline $\begin{array}{c}\text { Central Government } \\
\text { capital spending (10e6 E) }\end{array}$ & $\begin{array}{l}-0.0011 \\
(.0107)\end{array}$ & $\begin{array}{l}-0.0094 \\
(.011)\end{array}$ & $\begin{array}{l}-0.0020 \\
(.0108)\end{array}$ & $\begin{array}{l}-0.0016 \\
(.010)\end{array}$ & $\begin{array}{l}-0.0114 \\
(.011)\end{array}$ & $\begin{array}{l}-0.0137 \\
(.0096)\end{array}$ \\
\hline Population (10e6) & $0.1280(.194)$ & $-0.0701(.110)$ & $\begin{array}{l}-0.0034 \\
(.017)\end{array}$ & & & \\
\hline GDP per capita (10e3 E) & $\begin{array}{l}0.0131 \\
(.019)\end{array}$ & $\begin{array}{l}-0.0051 \\
(.0064)\end{array}$ & $\begin{array}{c}-0.0108^{* *} \\
(.0043)\end{array}$ & & & \\
\hline Prob $>\mathrm{F}$ & 0.9966 & 0.0000 & - & 0.9968 & 0.0000 & - \\
\hline Observations & 190 & 190 & 190 & 190 & 190 & 190 \\
\hline
\end{tabular}

Table 2c: Robustness check. Estimated Coefficients Composition of Public Expenditures. Regions with low level of competencies.

A last question to answer regarding the validity of the results, concerns the functional clasification of public expenditure described on section 4.2 and appendix 1. Decentralization has affected mainly to policies on Education and Health. In the fuctional clasification made by the Spanish authorities those fuctional categories of expenditure are included together under the denomination of "Social Public goods ". The fact that the decentralization process affects some categories more than others could be a source of distortion on the results since some functional categories of expenditure are by nature more related to expenditure in capital than others. As an example, we can check in the data described in appendix I that public expenditure in economic public goods, which includes expenditure in "Transport and Communication", does imply a higher share of capital to current expenditure than for example "Social Security" or "Social Public Goods ". For that reason we have estimated equation [], using data of regional public expenditure only on the category "Social Public Goods ". We present the data used for the construction of the variables "cap " and "dec" used in this estimation in Appendix III. The coefficients used as a dependent variable, capital to total expenditure, and as an explanatory variable, decentralization measure are constructed from regional and national data regarding only expenditure on 'Social Public Goods', which at the end of the period considered counts for more than a half of the total budget of the regionals governments. 


\begin{tabular}{|c|c|c|c|c|c|c|}
\hline & (1) & (2) & (3) & (4) & (5) & (6) \\
\hline & First Differences & $\begin{array}{l}\text { Fixed Effects } \\
\text { (AR1) }\end{array}$ & $\begin{array}{l}\text { Random Effects } \\
\text { (AR1) }\end{array}$ & First Differences & $\begin{array}{l}\text { Fixed Effects } \\
\quad \text { (AR1) }\end{array}$ & $\begin{array}{l}\text { Random Effects } \\
\text { (AR1) }\end{array}$ \\
\hline Fiscal decentralization & $\begin{array}{c}-0.00702^{* * * *} \\
\quad(.001)\end{array}$ & $-0.0093^{* * *}(.001)$ & $-0.0083^{* * *}(.001)$ & $\begin{array}{c}-0.0064^{* * *} \\
(.0018)\end{array}$ & $-0.0076^{* * *}(.001)$ & $-0.0096^{* * *}(.001)$ \\
\hline $\begin{array}{l}\text { Capital stock per capita } \\
\qquad(10 \mathrm{e} 3 \mathrm{E})\end{array}$ & $0.0189(.013)$ & $-0.0047(.005)$ & $-0.00101(.001)$ & $0.0124(.011)$ & $-0.0011(.004)$ & $-0.0012(.001)$ \\
\hline $\begin{array}{l}\text { Central Govern ment } \\
\text { capital spending (10e6 } \\
\text { E) }\end{array}$ & $-0.00717(.0001)$ & $-0.0130(.019)$ & $-0.0353^{*}(.018)$ & $-0.0116(.0183)$ & $-0.0079(.018)$ & $-0.0436^{* * *}(.016)$ \\
\hline Population (10e6) & $0.216^{*}(.118)$ & $0.0591(.081)$ & $-0.0316^{* * *}(.009)$ & & & \\
\hline GDP per cap ita (10e3 E) & $0.0079(.013)$ & $0.0102(.008)$ & $-0.0049(.005)$ & & & \\
\hline Prob $>F$ & 0.9855 & 0.0008 & - & 0.0037 & 0.0000 & - \\
\hline Observations & 221 & 221 & 238 & 221 & 221 & 238 \\
\hline \multicolumn{7}{|c|}{$\begin{array}{l}\text { *** Significant with a } 1 \% \text { confidence interval } \\
\text { ** } 5 \% \text { confidence interval } \\
\text { * } 10 \% \text { confidence interval }\end{array}$} \\
\hline
\end{tabular}

Table 2d: Robustness check. Estimated Coefficients Composition of Public Expenditures. Public Expenditure in Social Public Goods.

The results are again very conclusive regarding the significance of the variable of interest 'Fiscal decentralization'. However, from the comparison with the previous tables we can observe how the absolute value of the coefficients estimated are far smaller. The explanation to this fenomena is the different sensitivity that the construction of this ratio has using data only for 'Social Public Goods ' in comparison to the one used before with total expenditure data. Fiscal decentralization is 'more volatile', since the denominator of this ratio, i.e. central government expenditure, is quite smaller.

In the control variables we can observe also smaller levels of significance, although the variable 'Population' and 'Central Government Capital Expenditure' maintain similar patterns of behaviour than the one shown above.

\section{Conclusions.}

This paper sought to shed light on the relationship between fiscal decentralization and public expenditure composition. In particular, we want to examine the different patterns of behaviour regarding fiscal policy that decentralized economies present in comparison to centralized countries.

We investigate this issue from a theoretical point of view, with the use of a distance-sensitive representative agent model. We do assume that this distancesensitiveness towards public expenditure appears only when the agent is 'consuming ' current expenditure, while the actitude of the representative agent to public capital expenditure may be independent to the distance to the level of administration that provide the public good. This could explain that decentralized governments spend a smaller share of their budget on public capital. 
The spanish economy has experienced one of the fastest process of decentralization in Europe since the arrival of the democracy on 1978. This process has also been very peculiar, since the development of the regional governments have been quite asymetric and even now, some of them present significant differences in their levels of fiscal autonomy. With data from the spanish economy, we test the hypothesis that decentralized regions do spend a higher share of their budget to current expenditure than centralized ones. The results are very conclusive and robust to several sensitiveness analysis that have been run to the original equation: decentralization is a crutial factor to explain the share of public expenditure devoted to capital. Decentralized economies do devote a smaller share of their budget to public capital, in contrast to public current expenditure.

The policy implications of our findings may be quite controversial. While the result suggest that in efficiency terms a certain level of decentralization may be desirable, it also imply a reduction on the provision of public capital. Although it is not the aim of the present investigation, this result opens a door towars future lines of research. In particular, whether this reduction of public expenditure on capital may have any negative implications on the efficency of the production factors, as many theoretical models would suggest.

\section{Bibliography}

ALESINA, A. and SPOLAORE, E. (1997), 'On the number and size of nations ', Quarterly Journal of Economics, 112.

ALESINA, A., BAQIR, R. and EASTERLY, W. (1999), 'Public Goods and Ethnic Divisions ', Quarterly Journal of Economics, 114 (4).

ARONSSON, T and WIKSTROM, M. (1996), 'Local Public Expenditure in Sweeden: A Model where the Median Voter is not Necessariy Decisive', European Economic Review, 40.

ASCHAUER, D.A. (1989), 'Is Public Expenditure Productive? ', Journal of Monetary Economics, 23 (2).

ARZE, F.J., MARTINEZ VAZQUEZ, J. and MCNAB, R. (2005), 'Fiscal Decentralization and the Composition of Public Expenditures', International Studies Program Working Paper, 05-01.

BAI, J. and NG, S. (2004), 'A Panic Attack on Unit Roots and Cointegration ', Econometrica, 70.

BAJO-RUBIO, O. and SOSVILlA-RIVERO, S. (1993), 'Does Public Capital affct Private Sector Performance? An Analysis of the Spanish Case, 1964-88', Ecomic Modelling, 9 (3).

BARRO, R.J, (1990), "Government Spending in a Simple Model of Endogenous Growth ", Journal of Political Economy, 98 (5). 
BARRO, R.J. (1991), "Economic growht in a cross section of countries ", The Quarterly Journal of Economics, Vol. 106 No.2

BESLEY, T. and COATE, S. (2003), 'Centralized versus Decentralized Provision of Local Public Goods: a Political Economy Approach ', Journal of Public Economics, 87.

BRUECKNER, J.K (2005), 'Fiscal Federalism and Economic Growth ', University of California Working Paper.

DAVOODI, H. and ZOU, H. (1998), 'Fiscal decentralization and economic growth: a cross-country study', Journal of Urban Economics, 43.

DE HAAN, J., STURM, J.E. and SIKKEN, B.J. (1996), "Government Capital Formation: Explaining the Decline ", Weltwirtschaftliches Archiv, vol $132(1)$.

DESTEFANIS, S. and SENA, V. (2005), 'Public Capital and Total Factor Productivity: New Evidence from the Italian Regions, 1970-98 ', Regional Studies, 39 (5).

DEVARAJAN, S, SWAROOP, V. and ZOU, H. (1996), 'The Composition of Public Expenditure and Economic Growth', Journal of Monetary Economics, 37.

EISNER, R (1991), 'Infraestructure and Regional Economic Performance ', New England Economic Review.

ESCRIBA PEREZ, F.J. and MURGUI GARCIA, M.J. (1998), 'La Productividad Total de los Factores entre Sectores y Regiones en la Economía Espanyola. 1980-1993 ', Dirección General de Análisis y Programación Presupuestaria (Ministry of Economy of Spain) Working paper 98005.

EVERAERT, G. and HEYLEN, F. (2001), 'Public Capital and Productivity Growth: Evidence for Belgium, 1953-1996 ', Economic Modelling, 18.

FAGUET, J.P. (2002), 'A model of Central versus Decentralized Government: Self-Interest and Mis-allocation in Bolivia ', London School of Economics Working Paper 02-39.

FAGUET, J.P. (2004), 'Does Decentralization increase Government Responsiveness to Local Needs?: Evidence from Bolivia', Journal of Public Economics, 88.

FALCH, T. and RATTSO, J. (1997), 'Political Economy and Economic Determinants od School Spending in Federal States: Theory and Time-Series Evidence', European Journal of Political Economy, 13.

GERDTHAM, U.G., SOGAARD, J. JONSSON, F. and ANDERSSON, F. (1992), 'An Econometric Analysis of Health Care Expenditure: a Cross Section of OEDC Countries ', Journal of Health Economics, 11.

IIMI, A. (2004), 'Decentralization and Economic Growth Revisited: An Empirical Note', Japan Bank for International Cooperation Working Paper n. $17 / 2004$. 
IM, K.S., PESARAN, M.H. and SHIN, Y. (2003), 'Testing for Unit Roots in Heterogeneous Panels ', Journal of Econometrics, 115.

KNELLER, R., BLEANEY, M.F. and GEMMELL N. (1999) "Fiscal policy and growth: evidence from OECD countries", Journal of Public Economics 74, 171-190.

LOCKWOOD, B. (2002), 'Distributive Politics and the Costs of Centralization', Review of Economic Studies, 69.

MARTINEZ VAZQUEZ, J. and MCNAB, R. (2003), 'Fiscal Decentralization and Economic Growth ', World Development, 31 (9).

MARTINEZ VAZQUEZ, J. and MCNAB, R.M. (2005), 'Fiscal Decenralization, Macrostability and Growth ', International Studies Program Working Paper, 05-06.

MOLERO, J.C (2001), 'Analysis of the Decentralization of the Public Spending in Spain ', Public Finance and Management, 1 (4).

OATES, W. E. (1972), Fiscal Federalism, New York: Harcourt, Brace, Jovanovich.

OATES, W.E. (1993), 'Fiscal decentralization and economic development', University of Maryland, Working Paper 93-4.

PANIZZA, H. (1999), 'On the Determinants of Fiscal Centralization: Theory and Evidence ', Journal of Public Economics, 74.

PEDRONI, P. (1997), 'Panel Cointegration, Asymptotic and Finite Sample Properties Pooled Times Series Tests, with Application to the PPP Hypothesis: New Results', Indiana University Working Papers.

PEDRONI, P. (1999), 'Critical Values for Cointegration Tests in Heterogeneous Panels with Multiple Regressors ', Oxford Bulletin of Economics and Statistics, 61.

PEDRONI, P. (2004), 'Panel Cointegration: Asympotic and Finite Sample Properties of Pooled Time Series Tests with an Application to the PPP Hypothesis', Econometric Theory, 20.

PHILLIPS, P.C.B and SUL, D. (2003), 'Dynamic Panel Estimation and Homogeneity Testing under Cross Section Dependence', Econometrics Journal, 6.

RAMIREZ, M (1998), 'Does Public Investment Enhance Labor Productivity Growth in Chile? A Cointegration Analysis ', North American Journal of Economics and Finance, 9 (1). 
RANDOLPH, S., BOGETIC, Z. and HEFLEY, D. (1996), "Determinants of public expenditure on Infrastructure. Transport and Communication ", World Bank Policy Reseach Working Paper 1661.

RODDEN, J. and WIBBELS, E. (2002), 'Beyond the Fiction of Federalism: Macroeconomic Management in Multitiered Systems', World Politics, 54 (4).

RUBINCHIK-PESSACH, A. (2005), 'Can Decentralization be Beneficial? ', Journal of Public Economics, 89.

SANZ, I. and VELAZQUEZ, F.J. (2002), 'Determinants of the Composition of Government Expenditure by Functions ', European Economy Group Working Paper, 13/2002.

STURM, J.E. (2001), "Determinants of Public Capital Spending in lessdeveloped Countries ", CESinfo, Munich.

THIESSEN, U. (2003), 'Fiscal Decentralisation and Economic Growth in High-Income OECD Countries', Fiscal Studies, 24 (3).

TREISMAN, D (2000), 'Decentralization and Inflation: Commintment, Collective Action or Continuity ', Americal Political Science Review, 94 (4).

URBAIN, J.P. (1992), 'On Weak Exogeneity in Error Correction Models', Oxford Bulletin of Economics and Statistics, 54.

WEINGAST, B.R. (1995), 'The Ecomomic Role of Political Institutions: Market-preserving Federalism and Economic Development', Journal of Law, Economics and Organizations, 11 (1).

WOLLER, G. M. and PHILLIPS, K. (1998), 'Fiscal decentralization and LDC economic growth: an empirical investigation', Journal of Development Studies, 34 (4).

WOOLDRIDGE, J. (2002), "Econometric Analysis of Cross Section and Panel Data ", MIT Press, Cambridge, US.

XIE, D., ZOU, H. and DAVOODI, H. (1999), 'Fiscal decentralization and economic growth in the United States', Journal of Urban Economics, 45. 


\section{Appendix I}
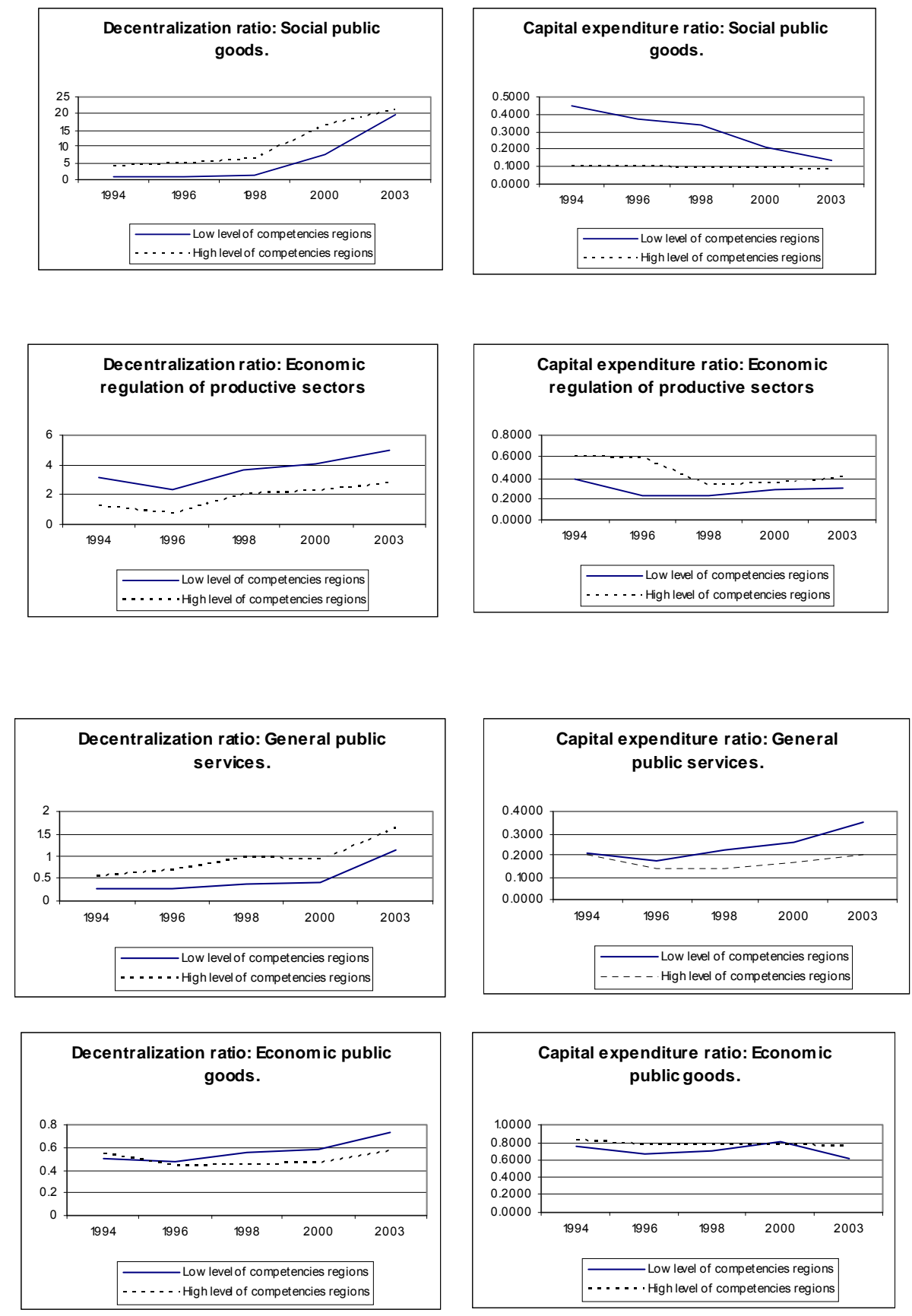
Data source: Presupuestos de las Comunidades Autónomas. Several years.

\section{Appendix II}

The graphs show the different nature of income between the two regions with 'Régimen Foral' and the rest. The category tax revenues includes all the taxes whose control lies in regional governments as well as the participation that they have in other taxes collected by the central government. We can see how in the revisions introduced for the period 1991-1996 and specially that of 1997-2001 have produced a great increase on tax income that have substituted part of the Participation on the Revenues of the State (PRS).



Sources of revenues: Regions with low level of competencies

The category Social Security and ordinary transfers includes basically two main components. The first one is the translation of funds from the Social Security organism (Tesorería General de la Seguridad Social) to the regions to face the expenditure regarding social security (mainly Health ${ }^{23}$ ). The second main component is the PRS, that counts for the transfers from the central government to finance the competencies assumed by the regions. It is calculated according

\footnotetext{
${ }^{23}$ The regions complete their expenditure in Health policies with other complementary funds from the central government (or deduced from the amount to be paid, in the case of Vasc Country and Navarra) given that the amount provided by the Social Security cuotas is declared to be insufficient.
} 
to economical, demographical and political variables and taking into account the different amount of competencies that the regions may assume (many of them are assumed freely).

The category operations of intermediation counts for the transfers from central government and European Funds in which the regions are only the 'link' between the funds provider and their destination. Other revenues includes a quite heterogeneous sources of revenues, among them the Fund of Interterritorial Compensation (FCI $)^{24}$ and public debt ${ }^{25}$.

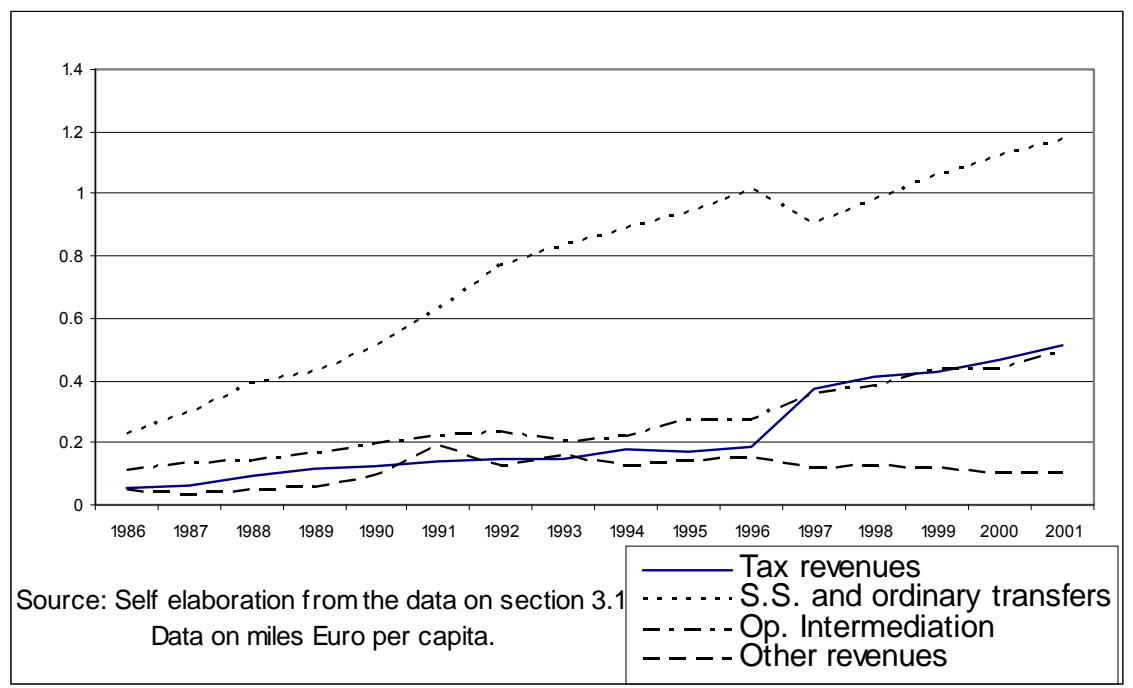

Sources of Revenues: Regions with high level of competencies (Ex. Navarra and Vasc Country)

\footnotetext{
${ }^{24} \mathrm{An}$ incentive to develop the regions with lower production per capita. It is a fund provided conditioned to be invested on activities that enhance growth.

${ }^{25}$ Ocasionally, the value of this category lies under cero, precisely because of the effect of the amortization of public debt.
} 


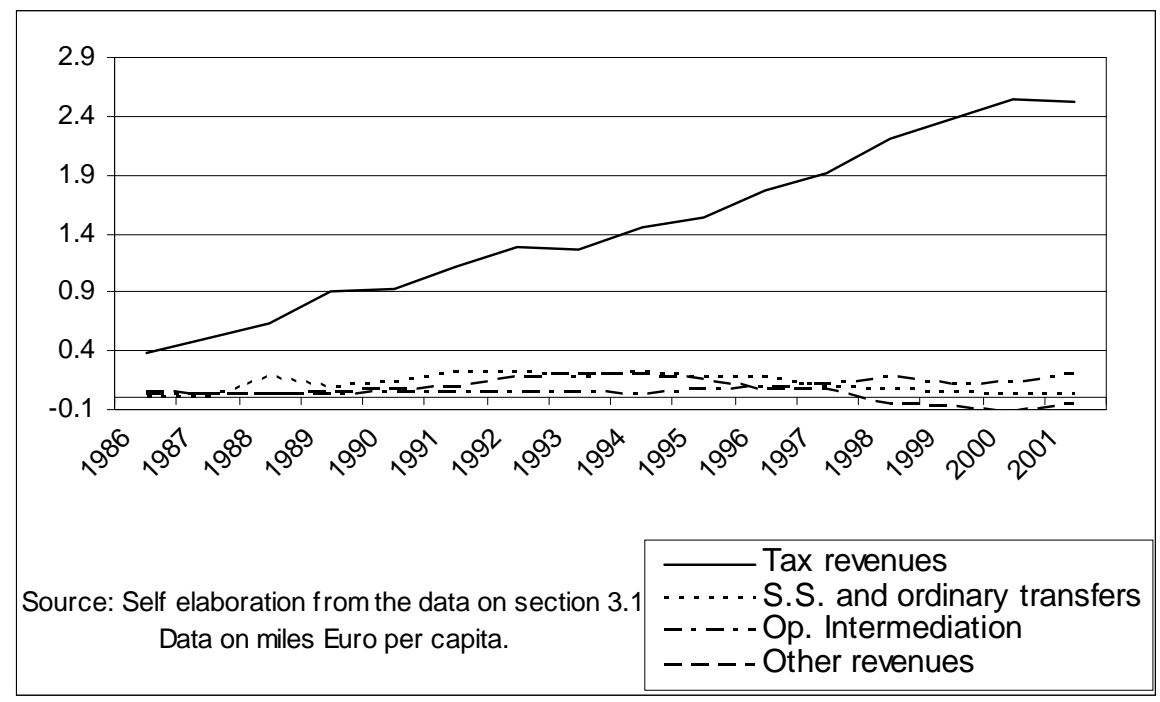

Sources of Revenues: Navarra and Vasc Country

\section{Appendix III}

The ratios for the variables "cap" and "dec" used in estimations presented in tables 2 to $2 \mathrm{c}$, are built from data on regional and national public expenditure obtained from the BADESPE database and from the INE respectively. For table $2 \mathrm{~d}$ we use instead more disaggregated data. The variable cap is constructed as the ratio of public capital expenditure on "Social Public Goods" to total public expenditure on "Social Public Goods ", for every regional government. The variable "dec" is the ratio of total public expenditure on "Social Public Goods" run by every regional government to the equivalent value for the central government. Data for regional public expenditure are obtained from the Yearbook "Presupuestos de las Comunidades Autonomas", edited by the Spanish Ministry of Economy and Finance. Data for central government public expenditure on "Social Public Goods " are obtained from the INE database.

\begin{tabular}{||c||c||c||c||c||c||}
\hline \hline & $\mathrm{N}$ & mean & St. Deviation & minimum & maximum \\
\hline \hline cap & 239 & .261243 & .1712795 & .0454189 & .768716 \\
\hline \hline dec & 238 & 7.009455 & 7.833562 & .3234651 & 28.70418 \\
\hline \hline \multicolumn{5}{|l|}{} \\
\hline \hline
\end{tabular}


Table [3] presents the Summary Statistics for the versions of the variables "cap" and "dec" used to estimate equation [] in table 2d. The remaining control variables remain inaltered in comparison to the original estimation presented in table 2. The decentralization ratio changes dramatically in comparison to the one used originally. That is because the level of decentralization in policies regarding social policy, specially Education and Health, is far larger that the average decentralization. Regional governments control the mayor part of public expenditure devoted to those policies, while the central government plays a residual role. 